\title{
AVALIAÇÃO METABÓLICA DE VACAS LEITEIRAS ALIMENTADAS COM GRÃO DE SOJA CRU E TRATADO COM CALOR*
}

\author{
MARILIA DE FARIA CORRÊA CELESTINO ALVES
}

Félix Hilário Diaz González (Orientador -UFRGS)

Banca Examinadora:

Francisco Augusto Burkert Del Pino UFPel

Marcelo da Silva Cecim UFSM

Paulo Roberto Frenzel Mühlbach UFRGS

O grão e o farelo de soja vêm sendo utilizados como fonte protéica na alimentação de vacas leiteiras no Rio Grande do Sul. Entretanto, a elevada degradabilidade ruminal desta fonte, ao mesmo tempo que causa perda da qualidade intrínseca da proteína, leva a aumento da uréia plasmática, com conseqüências deletérias no metabolismo dos animais. $\mathrm{O}$ tratamento térmico do grão de soja pode superar essa limitação. Este trabalho teve como objetivo avaliar o metabolismo de vacas leiteiras alimentadas com grão de soja cru e tratado termicamente, através da análise do perfil metabólico no plasma e no leite. Foram utilizadas doze vacas da raça Holandesa, no terço médio da lactação, nas quais foram aplicados quatro tratamentos com fontes protéicas diferentes: concentrado protéico comercial, farelo de soja, grão de soja cru e grão de soja tostado. No plasma foram determinados componentes energéticos, protéicos, minerais e indicadores da função hepática. No leite foram dosados os teores de proteína e uréia. Não foram detectadas alterações hepáticas e nem na concentração de glicose, betahidroxibutirato, cálcio, fósforo e magnésio. Houve maiores níveis de colesterol plasmático nos animais consumindo grão de soja (cru e tratado com calor). As vacas consumindo soja tostada tiveram menor teor de uréia no plasma, sugerindo que o tratamento com calor no grão de soja foi efetivo para diminuir a degradação protéica no rúmen e melhorar a relação energia/proteína da ração.

Descritores: soja tostada, proteína, uréia, energia, leite. 


\title{
METABOLIC EVALUATION OF DAIRY COWS FED HEAT TREATED OR RAW SOYBEANS**
}

\author{
MARILIA DE FARIA CORRÊA CELESTINO ALVES
}

Félix Hilário Diaz González (Adviser -UFRGS)

Banca Examinadora:

Francisco Augusto Burkert Del Pino UFPel

Marcelo da Silva Cecim UFSM

Paulo Roberto Frenzel Mühlbach UFRGS

Soybean and soybean meal are currently being used in Rio Grande do Sul, Brazil as a source of protein when feeding dairy cows. However, the high break down of this source in the rumen causes a loss of the intrinsic quality of the protein, as well as an increase in plasma urea with deleterious consequences on the animal metabolism. Thermal treatment of soybean can overcame this limitation. The aim of this study was to evaluate the metabolism of dairy cows, fed with thermally treated soybean and raw soybean, through the analyses of the metabolic profile test of plasma and milk analyses. Twelve Holstein cows in the mid lactation period were studied. Four treatments, each with a different protein source, were used on these cows. These were: comercial concentrated of protein, soybean meal, raw soybean and roasted soybean. In the plasma, energy, protein and mineral components were determined as well as indicators of hepatic function. In the milk, the levels of protein and urea were measured. No hepatic alterations were detected. There were also no alterations in the glucose, beta-hidroxibutirate, calcium, phosphorus and magnesium concentration. There were higher levels of plasma cholesterol in the animals consuming both raw and thermally treated soybean. Cows consuming roasted soybean had lower level of urea in the plasma, suggesting that the use of heat treated soybean was effective in diminishing the break down of protein in the rumen and improving the energy/protein ratio of the ration.

Key words: roasted soybean, protein, urea, energy, milk. 